\title{
FACTORS ASSOCIATED WITH BLOOD TRANSFUSION IN THE POSTOPERATIVE PERIOD OF CARDIAC SURGERY
}

\author{
FATORES ASSOCIADOS À TRANSFUSÃO SANGUÍNEA NO PERÍODO PÓS- \\ OPERATÓRIO DE CIRURGIA CARDÍACA
}

\author{
Maria Helena BARBOSA ${ }^{1}$; Karla Fabiana N. da SILVA ${ }^{2}$; Érica Vieira de ANDRADE ${ }^{3}$; \\ Quênia Cristina Gonçalves da SILVA ${ }^{4}$; Daniela Aparecida SILVA ${ }^{5}$; Elizabeth BARICHELLO ${ }^{1}$ \\ 1. Doutora em Enfermagem na Saúde do Adulto, Professora Adjunto da Graduação e Pós-Graduação em Enfermagem da Universidade \\ Federal do Triângulo Mineiro - UFTM, Uberaba, MG, Brasil; 2. Enfermeira. Mestre em Atenção à Saúde, Docente do Centro de \\ Educação Profissional - Cefores - UFTM, Uberaba, MG, Brasil; 3. Enfermeira, Mestre em Atenção à Saúde pela UFTM, Uberaba, MG, \\ Brasil; 4. Enfermeira do Hospital de Clínicas da UFTM, Mestre em Atenção à Saúde pela UFTM, Uberaba, MG, Brasil; 5. Egressa do \\ Curso de Graduação em Enfermagem da UFTM, Uberaba, MG, Brasil.
}

\begin{abstract}
This study aims to identify the factors associated with blood transfusion in the postoperative period of cardiac surgery, and the predominant types of blood products used. Analytical and retrospective study carried out in a large teaching hospital located in Uberaba, Minas Gerais, Brazil. Data were collected from 460 medical records of patients who underwent cardiac surgery between July 2005 and July 2010. There were 290 (63\%) patients received blood transfusions in the intra- and/or postoperative period. The mean age was 57.9 years; $59.6 \%$ were male; $74.8 \%$ presented with systemic arterial hypertension as a comorbidity; and $97.2 \%$ of the surgeries were elective, with myocardial revascularization being the most prevalent type of surgery. In the intraoperative period, $75(25.9 \%)$ patients received blood transfusions, and in the postoperative period $273(94.1 \%)$ patients received blood transfusions, with red blood cell concentrate being the predominant type of blood product used. There was a statistically significant association between postoperative blood transfusion and the variables age group, complications and intraoperative blood transfusion. Blood transfusion remains a frequent procedure in cardiac surgeries, and age group, complications and intraoperative blood transfusion were independent predictors for postoperative blood transfusion.
\end{abstract}

KEYWORDS: Cardiac surgery procedures. Blood transfusion. Epidemiology. Risk factors.

\section{INTRODUCTION}

Cardiovascular disease has become the primary cause of morbimortality in Brazil. Cardiac surgery is an option when useful life expectancy is longer with surgical treatment than with clinical treatment (GALDEANO et al., 2012). Given the complexity of this surgical procedure, blood transfusions are often necessary in the perioperative period. Many factors can increase the risk of bleeding for these patients, which can result in blood transfusion during or following cardiac surgery (HALL et al., 2001; SOUZA; MOITINHO, 2008;).

Although it is a common procedure in highly complex surgeries, blood transfusion is not without risk, such as the occurrence of immediate or late transfusion reactions. According to Souza and Barbosa (2011; 2012), non-hemolytic fever and allergic reaction are among the common immediate reactions, primarily due to the concentration of red blood cells. Additionally, researchers have concluded that postoperative blood transfusion for cardiac surgery is associated with atrial fibrillation, stroke and acute renal failure, as well as infection of the respiratory tract, mediastinitis and sepsis (DORNELES et al., 2011).

According to Souza and Moitinho (2008), some health care services have adopted strategies for reducing the use of blood products in patients undergoing cardiovascular surgery. However, studies that highlight factors related to postoperative blood transfusion are scarce.

Thus, the objective of this study was to identify factors associated with blood transfusion in the postoperative period of cardiac surgery, and the predominant types of blood products used.

\section{MATERIAL AND METHODS}

\author{
Study design \\ This is a retrospective, analytical study with \\ a quantitative approach.
}

\section{Ethical considerations}

This study is part of a larger project entitled "Occurrence of hospital infections in patients undergoing cardiac surgery," approved by the Research Ethics Committee of the Universidade Federal do Triângulo Mineiro, under protocol number 1611/2012. 


\section{Setting and samples}

Data were obtained from 460 medical records of patients who underwent cardiac surgery between July 2005 and July 2010, in a large public teaching hospital located in Uberaba, Minas Gerais, Brazil. The Cardiac Surgery Service of the study hospital provided the numbers for the patient charts, which were then accessed by the Medical Records Service. The study included patients aged 18 years or over who underwent cardiac surgery. Patients whose medical record numbers were not identified or located were excluded from the study.

\section{Data collection}

An instrument was developed to guide data collection, which was evaluated by three specialists in this subject matter.

\section{Analyzed variables}

The variables analyzed were: sex, age, origin, body mass index (BMI), clinical condition according to the American Society of Anesthesiologists (2010), tobacco smoking, comorbidities, pre- and postoperative hospitalization time, use of antiplatelet drugs, classification, type and duration of surgery, use and length of time spent on cardiopulmonary bypass (CPB), sternal reopening, intraoperative blood transfusion, type and quantity of blood product used, and patient outcome (discharge, death or transfer).

\section{Measurements}

The BMI variable was classified according to the definition by the World Health Organization (1998): underweight $\left(<18.5 \mathrm{~kg} / \mathrm{m}^{2}\right)$, normal weight (18.5 to $\left.24.9 \mathrm{~kg} / \mathrm{m}^{2}\right)$, overweight $(25.0$ to 29.9 $\left.\mathrm{kg} / \mathrm{m}^{2}\right)$, class I obesity ( 30.0 to $34.9 \mathrm{~kg} / \mathrm{m}^{2}$ ), class II obesity ( 35.0 to $39.9 \mathrm{~kg} / \mathrm{m}^{2}$ ) and class III obesity ( $\geq$ $\left.40.0 \mathrm{~kg} / \mathrm{m}^{2}\right)$.

The clinical condition variable was classified according to the Physical Status Classification System of the American Society of Anesthesiologists (2010): P1 (healthy patient), P2 (patient with mild systemic disease), P3 (patient with severe systemic disease), P4 (patient with severe systemic disease that is a constant threat to life), P5 (moribund patient who is not expected to survive without surgery), and P6 (brain-dead patient whose organs are being removed for donation).

\section{Data analysis}

The data collected was entered twice into a Microsoft Excel ${ }^{\circledR}$ spreadsheet, and was subsequently validated. After being validated, the data was exported to Statistical Package for Social Sciences (SPSS), version 17, for analysis.
The qualitative variables were analyzed using descriptive statistics through distribution of absolute and percentage frequency. For the quantitative variables, the descriptive measurements of centrality (mean) and dispersion (minimum and maximum values) were used.

In order to identify the factors associated with blood transfusion in the postoperative period of cardiac surgery, a bivariate analysis was performed using the chi-squared test, with a significance level of 0.05 . Following, multivariate analysis through logistic regression was performed, considering the variables presented in the bivariate analysis value of $p<0.1$. The significance level of 0.05 was also adopted in the multivariate model. Note that in order to proceed to the bivariate and multivariate analyses, all of the studied variables were dichotomized.

\section{RESULTS}

\section{General characteristics}

In the period analyzed, of the 460 patients who comprised the study population, 290 (63.0\%) received blood transfusions in the intra and/or postoperative period. The mean age of the study subjects was 57.9 years, with variation from 20 to 81 years; $173(59.6 \%)$ of the patients were male, and $189(65.2 \%)$ were from the municipality of Uberaba (MG). The mean BMI was $25.4 \mathrm{~kg} / \mathrm{m}^{2}$, and $71(24.5 \%)$ of the patients were overweight. In regards to clinical condition according to the American Society of Anesthesiologists, 71 (24.5\%) of the patients were classified as P3 (patients with severe systemic disease). In regards to tobacco use, $88(30.3 \%)$ of the patients were smokers, 85 $(29.3 \%)$ were non-smokers and $72(24.8 \%)$ were former smokers.

In regards to primary comorbidities, it was verified that $217(74.8 \%)$ of the patients had systemic arterial hypertension (SAH), 75 (25.9\%) had diabetes mellitus (DM), 41(14.1\%) had chronic obstructive pulmonary disease (COPD), 25 (8.6\%) had congestive heart failure (CHF), 13 (4.5\%) had chronic renal failure, four $(1.4 \%)$ had acute renal failure, and two $(0.7 \%)$ had immunosuppressive disease.

\section{Characteristics related to surgery and blood transfusion}

The mean preoperative hospitalization time was 7.9 days, with variation from one to 54 days. The mean preoperative hospitalization time in the intensive care unit (ICU) was 5.4 days, with variation from one to 26 days. The majority of the surgeries $(282 ; 97.2 \%)$ were classified as elective, 
and the mean duration time of the procedures was 4.1 hours, with variation from 1.9 to nine hours. Myocardial revascularization (MRV) was the most prevalent surgery, performed on 140 (48.3\%) patients (Table 1). The majority of the surgeries (97.9\%) used CPB for a mean time of 83.4 minutes, with variation from ten to 260 minutes.

Table 1. Distribution of frequency of patients who received blood transfusions in the intra- and/or postoperative period $(n=290)$, according to cardiac surgery performed. Uberaba-MG, 2005-2010.

\begin{tabular}{lcc}
\hline Surgery & n & \% \\
\hline MRV & 140 & 48.3 \\
MVR & 49 & 16.9 \\
AVR $_{\mathrm{O}}$ & 44 & 15.2 \\
MVR+AVR $_{\mathrm{O}}$ & 10 & 3.4 \\
MRV+ AVR & 3.1 \\
MRV+ MVR & 9 & 2.1 \\
Bentall & 6 & 1.7 \\
IAC & 5 & 1.4 \\
IVC & 4 & 0.3 \\
Other & 1 & 7.6 \\
& 22 & 100.0 \\
\hline
\end{tabular}

MRV: myocardial revascularization, MRV: mitral valve replacement. $\mathrm{AVR}_{\mathrm{O}}$ : aortic valve replacement, IAC: interatrial communication, IVC: interventricular communication

Seventy-five (25.9\%) patients received blood transfusions during the intraoperative period; of these, $42(56.0 \%)$ received only one type of blood product, and $33(44.0 \%)$ received more than one type. Red blood cell concentrate was the most frequently administered blood product, and a total of 125 units were used on $57(76.0 \%)$ patients (Table 2).

Table 2. Distribution of types and quantity of blood products used in the intraoperative period of cardiac surgery. Uberaba-MG, 2005-2010.

\begin{tabular}{lcccc}
\hline Types of blood components used & \multicolumn{2}{c}{$\begin{array}{c}\text { Transfused patients } \\
(\mathbf{n = 7 5})\end{array}$} & Total transfused units & Mean units/patient \\
\cline { 2 - 3 } & $\mathbf{n}$ & $\boldsymbol{\%}$ & & \\
\hline Red blood cell concentrate & 57 & 76 & 125 & 2.2 \\
Fresh frozen plasma & 29 & 38.7 & 99 & 3.4 \\
Platelet concentrate & 28 & 37.3 & 267 & 9.5 \\
Cryoprecipitate & 11 & 14.7 & 121 & 11.0 \\
\hline
\end{tabular}

It was verified that $86(29.6 \%)$ patients used antiplatelet drugs during the preoperative period, and $222(76.6 \%)$ in the postoperative period. Nine patients $(3.1 \%)$ underwent sternal reopening due to bleeding in the immediate postoperative period.

In the postoperative period, $273(94.1 \%)$ patients received blood transfusions. Of these, 178 (65.2\%) received just one type of blood product, and $95(34.8 \%)$ patients received more than one type. Red blood cell concentrate was the predominant type of blood product used in the postoperative period, with a total of 965 units transfused in 265 (97.1\%) patients (Table 3).

In regards to the total postoperative hospitalization time, it was observed that the mean length of stay was 14 days, with variation from three to 76 days. The mean postoperative hospitalization time in the ICU was 9.3 days, with variation from two to 70 days. In regards to outcome of the study subjects, $240(82.8 \%)$ were discharged from the hospital, and $50(17.2 \%)$ died. 
Table 3. Distribution of types and quantity of blood products used in the postoperative period of cardiac surgery. Uberaba, Minas Gerais, 2005-2010.

\begin{tabular}{lcccc}
\hline $\begin{array}{l}\text { Types of blood components } \\
\text { used }\end{array}$ & \begin{tabular}{c} 
Transfused patients $(\mathbf{n = 2 7 3})$ \\
\cline { 2 - 3 }
\end{tabular} & & $\begin{array}{c}\text { Total units } \\
\text { transfused }\end{array}$ & $\begin{array}{c}\text { Mean units/ } \\
\text { patient }\end{array}$ \\
\cline { 2 - 3 } & $\mathbf{n}$ & $\mathbf{\%}$ & & \\
\hline Red blood cell concentrate & 265 & 97.1 & 965 & 3.6 \\
Fresh frozen plasma & 93 & 34.1 & 353 & 3.8 \\
Platelet concentrate & 43 & 15.7 & 408 & 9.5 \\
Cryoprecipitate & 14 & 5.1 & 157 & 11.2 \\
\hline
\end{tabular}

\section{Factors associated with blood transfusion}

In regard to factors that may be associated with blood transfusion in the postoperative period of cardiac surgery, the bivariate analysis showed that age group, presence of $\mathrm{SAH}$, presence of $\mathrm{COPD}$, length of surgery, occurrence of complications in the intraoperative period, and blood transfusion in the intraoperative period were factors that were statistically significant $(p<0.05)$ (Table 4$)$.

Table 4. Bivariate analysis of risk factors and blood transfusion in the postoperative period of cardiac surgery. Uberaba, Minas Gerais, 2005-2010.

\begin{tabular}{|c|c|c|c|c|c|}
\hline \multirow{3}{*}{ Variables } & \multicolumn{4}{|c|}{ Blood transfusion in the post-operative period } & \multirow{3}{*}{$p$} \\
\hline & \multicolumn{2}{|c|}{ Yes } & \multicolumn{2}{|c|}{ No } & \\
\hline & $\mathbf{n}$ & $\%$ & $\mathbf{n}$ & $\%$ & \\
\hline \multicolumn{6}{|l|}{ Sex } \\
\hline Male & 167 & 59.6 & 113 & 40.4 & \multirow{2}{*}{0.872} \\
\hline Female & 106 & 58.9 & 74 & 41.1 & \\
\hline \multicolumn{6}{|l|}{ Age group } \\
\hline Elderly & 132 & 71.4 & 53 & 28.6 & \multirow{2}{*}{$<0.001$} \\
\hline Adult & 141 & 51.3 & 134 & 48.7 & \\
\hline \multicolumn{6}{|l|}{ DM } \\
\hline Yes & 69 & 65.7 & 36 & 34.3 & \multirow[b]{2}{*}{0.131} \\
\hline No & 204 & 57.5 & 151 & 42.5 & \\
\hline \multicolumn{6}{|l|}{ SAH } \\
\hline Yes & 205 & 63.1 & 120 & 36.9 & \multirow{2}{*}{0.012} \\
\hline No & 68 & 50.4 & 67 & 49.6 & \\
\hline \multicolumn{6}{|l|}{ COPD } \\
\hline Yes & 39 & 75.0 & 13 & 25.0 & \multirow{2}{*}{0.015} \\
\hline No & 234 & 57.4 & 174 & 42.6 & \\
\hline \multicolumn{6}{|l|}{ Use of CPB } \\
\hline Yes & 268 & 59.7 & 181 & 40.3 & \multirow{2}{*}{0.342} \\
\hline No & 5 & 45.5 & 6 & 54.5 & \\
\hline \multicolumn{6}{|c|}{ Duration of Surgery } \\
\hline 4 hours or more & 133 & 69.3 & 59 & 30.7 & \multirow{2}{*}{$<0.001$} \\
\hline Less than 4 hours & 140 & 52.2 & 128 & 47.8 & \\
\hline \multicolumn{6}{|c|}{$\begin{array}{l}\text { Complications in the } \\
\text { intraoperative period }\end{array}$} \\
\hline Yes & 28 & 82.4 & 6 & 17.6 & \multirow{2}{*}{0.005} \\
\hline No & 245 & 57.5 & 181 & 42.5 & \\
\hline \multicolumn{6}{|c|}{$\begin{array}{l}\text { Blood transfusion in the } \\
\text { intraoperative period }\end{array}$} \\
\hline Yes & 58 & 77.3 & 17 & 22.7 & \multirow{2}{*}{0.001} \\
\hline No & 215 & 55.8 & 170 & 44.2 & \\
\hline
\end{tabular}




\begin{tabular}{lccccc}
\hline $\begin{array}{l}\text { Use of AP* in the } \\
\text { postoperative period }\end{array}$ & & & & & \\
Yes & 210 & 60.5 & 137 & 39.5 & 0.370 \\
No & 63 & 55.8 & 50 & 44.2 & 0.2 \\
\hline$* \mathrm{AP}=$ Antiplatelet drugs & & & &
\end{tabular}

In the multivariate analysis, age group, intraoperative complications and intraoperative blood transfusion were factors that continued to be statistically significant $(p<0.05)$, and were considered independent predictors of blood transfusion in the postoperative period of cardiac surgery (Table 5).

Table 5. Logistic regression of factors associated with blood transfusion in the postoperative period of cardiac surgery. Uberaba, Minas Gerais, 2005-2010.

\begin{tabular}{|c|c|c|c|c|c|c|}
\hline \multirow{3}{*}{ Variables } & \multicolumn{4}{|c|}{$\begin{array}{l}\text { Blood transfusion in the } \\
\text { postoperative period }\end{array}$} & \multirow{3}{*}{ OR $(\mathrm{CI})^{*}$} & \multirow{3}{*}{$p$} \\
\hline & \multicolumn{2}{|c|}{ Yes } & \multicolumn{2}{|c|}{ No } & & \\
\hline & $\mathbf{n}$ & $\%$ & $\mathbf{n}$ & $\%$ & & \\
\hline \multicolumn{7}{|l|}{ Age group } \\
\hline Elderly & 132 & 71.4 & 53 & 28.6 & \multirow{2}{*}{$2.00(1.31-3.07)$} & \multirow{2}{*}{0.001} \\
\hline Adult & 141 & 51.3 & 134 & 48.7 & & \\
\hline \multicolumn{7}{|l|}{ SAH } \\
\hline Yes & 205 & 63.1 & 120 & 36.9 & \multirow{2}{*}{$1.15(0.73-1.79)$} & \multirow{2}{*}{0.551} \\
\hline No & 68 & 50.4 & 67 & 49.6 & & \\
\hline \multicolumn{7}{|l|}{ COPD } \\
\hline Yes & 39 & 75.0 & 13 & 25.0 & \multirow{2}{*}{$1.72(0.86-3.41)$} & \multirow{2}{*}{0.123} \\
\hline No & 234 & 57.4 & 174 & 42.6 & & \\
\hline \multicolumn{7}{|c|}{ Duration of Surgery } \\
\hline 4 hours or more & 133 & 69.3 & 59 & 30.7 & \multirow{2}{*}{$1.49(0.98-2.28)$} & \multirow{2}{*}{0.064} \\
\hline Less than 4 hours & 140 & 52.2 & 128 & 47.8 & & \\
\hline \multicolumn{7}{|c|}{$\begin{array}{l}\text { Complications in the } \\
\text { intraoperative period }\end{array}$} \\
\hline Yes & 28 & 82.4 & 6 & 17.6 & \multirow{2}{*}{$2.71(1.06-6.90)$} & \multirow{2}{*}{0.037} \\
\hline No & 245 & 57.5 & 181 & 42.5 & & \\
\hline \multicolumn{7}{|c|}{$\begin{array}{l}\text { Blood transfusion in the } \\
\text { intraoperative period }\end{array}$} \\
\hline Yes & 58 & 77.3 & 17 & 22.7 & $2.02(1.10-3.71)$ & \multirow{2}{*}{0.023} \\
\hline No & 215 & 55.8 & 170 & 44.2 & & \\
\hline
\end{tabular}

* Odds ratio (Confidence Interval)

\section{DISCUSSION}

Blood transfusion in cardiac surgery is very common, especially in MRV. Patients who undergo cardiac surgery tend to receive more blood transfusions than other surgery patients (WILLIAMS et al., 2011; MOHNLE et al., 2010; CAPRARO et al., 2007). According to Karkouti et al.(2006), the incidence of blood transfusion during cardiac surgery varies from $27.0 \%$ to $92.0 \%$.

A study by Shander et al. (2009) evaluated the need for blood transfusion in different types of surgeries, and observed that in orthopedic surgeries blood transfusion was necessary for only $15.7 \%$ of patients, while in cardiac surgeries the percentage rose to $55.6 \%$.

\section{Patient characteristics}

The mean age of patients in this study was 57.9 years. This result differs from other studies, in which the mean age was 64 years (BANBURY et al., 2006), 63.8 years for women, 61.8 years for men (WILLIAMS et al., 2011), 59.5 years (CHALEGRE et al., 2011) and 50.7 years, respectively (SOUZA; MOITINHO, 2008). In regards to gender, a prevalence of men was observed in this study, which is similar to other studies (BANBURY et al., 2006; KOCH et al., 2006; ROGERS et al., 2007; CHALEGRE et al., 2011; DORNELES et al., 2011; WILLIAMS et al., 2011). Given the reality of population aging, the findings of this study point out the importance of studies that focus on risk factors 
for heart disease, since the adult population was prevalent in this study.

The mean BMI observed in the study was $25.4 \mathrm{~kg} / \mathrm{m}^{2}$, which substantiates obesity as a risk factor for heart disease and is similar to the result of another study in which the mean BMI was $26 \mathrm{~kg} / \mathrm{m}^{2}$ (WERLANG et al., 2008). In other studies, $48.7 \%$ of men had a BMI between 25 and $29.9 \mathrm{~kg} / \mathrm{m}^{2}$, while $34.7 \%$ of women had a BMI less than 25 $\mathrm{kg} / \mathrm{m}^{2}$. Less than $1.0 \%$ of the patients who received blood transfusions had a BMI less than $20 \mathrm{~kg} / \mathrm{m}^{2}$ (ROGERS et al., 2007; VAN STRATEN et al., 2010).

In regards to clinical condition, a prevalence of patients with severe systemic disease (American Society of Anesthesiologists classification P3) was evident, which was similar to another study (SHANDER et al., 2009). Among the comorbidities, SAH was common, which was also observed in another study involving patients who received blood transfusions during cardiac surgery (BANBURY et al., 2006; KOCH et al., 2006; SOUZA; MOITINHO, 2008; ; WERLANG et al., 2008; MOHNLE et al., 2010; DORNELES et al., 2011; WILLIAMS et al., 2011).

\section{Characteristics of the surgery and blood transfusion}

The mean preoperative hospitalization time was 7.9 days, and the mean preoperative time spent in the ICU was 5.4 days, which differs from another study in which the mean time was two to three days (MANNIEN et al., 2011). It is worth noting that the lower preoperative hospitalization time, the lower the risk of postoperative complications occurring. The mean postoperative hospitalization time of 14 days corroborates another study in which the mean time was 13 days (DORNELES et al., 2011).

The majority of surgeries performed were elective, which corroborates other studies in which the frequencies of emergency surgeries were $2.3 \%$ and $8.4 \%$, respectively (BANBURY et al., 2006; VAN STRATEN et al., 2010). Similar to other studies, MRV was the type of cardiac surgery that most frequently required the use of blood transfusion (ROGERS et al., 2007; SOUZA; MOITINHO, 2008; WERLANG et al., 2008; DORNELES et al., 2011; MANNIEN et al., 2011).

In regard to the use of $\mathrm{CPB}$ in cardiac surgeries requiring blood transfusion in literature the majority used this method of support, with use sometimes approaching $100 \%$ of procedures (BANBURY et al., 2006; SOUZA; MOITINHO, 2008). One study showed that only $4.2 \%$ of cardiac surgeries with blood transfusion did not use CPB as a support (VAN STRATEN et al., 2010), and in another study, by Dorneles et al. (2011), only 3.4\% of patients underwent cardiac surgery without CPB. The mean duration of CPB was 83.4 minutes, which corroborated other studies with a mean time less than 120 minutes (LOURES et al., 2000; SOUZA; MOITINHO, 2008; MOHNLE et al., 2010).

Corroborating other studies, red blood cell concentrate was the predominant type of blood product used in blood transfusions (BANBURY et al., 2006; CAPRARO et al., 2007; MANNIEN et al., 2011; WILLIAMS et al., 2011). The mean number of units of red blood cell concentrate used in the intraoperative period was 2.2 units per patient, and 3.6 units per patient in the postoperative period. This data is considerably greater than the mean use of 1.45 units of red blood cell concentrate per patient in cardiovascular surgery (SOUZA; MOITINHO, 2008).

In regard to the use of other blood products during the intra-and postoperative periods, a large quantity of units transfused per patient was observed, with relatively higher frequencies of transfusions of plasma (34/1\%) and cryoprecipitate (5.1\%). In literature (SOUZA; MOITINHO, 2008), a mean use of 0.75 UI per patient of fresh frozen plasma was observed, along with 1.43 UI of thrombocytes per patient, and 0.89 UI of cryoprecipitate per patient. Another study showed that $21.0 \%$ of patients received transfusions of thrombocyte concentrate in the postoperative period, $13.0 \%$ received fresh plasma and $3.0 \%$ received cryoprecipitate (BANBURY et al., 2006).

It was shown that the primary blood product transfused in cardiac surgeries was red blood cell concentrate. One study showed that $34.5 \%$ of patients received at least one unit, $22.7 \%$ of patients received one to two units, $8.6 \%$ received between three to five units of red blood cell concentrate, 3.1 received between six to 10 units, and $0.7 \%$ of patients received more than 10 units of red blood cell concentrate, with a mean of 0.75 IU of red blood cell concentrate per patient (VAN STRATEN et al., 2010).

The high use of red blood cell concentrate in cardiac surgeries may be related to the risk of bleeding, which, according to Souza and Moitinho (2008), is one of the most frequent complications in cardiovascular surgeries. This would justify the consumption of this blood product.

In regards to sternal reopening, $3.1 \%$ of patients required this treatment due to bleeding. In another study, (DORNELES et al., 2011) showed that $1.98 \%$ underwent surgical re-exploration, also due to bleeding. 


\section{Factors associated with blood transfusion}

In regards to factors associated with blood transfusion in the postoperative period, following multivariate analysis it was shown that the variables age group, complications and intraoperative blood transfusion were independent predictors of the outcome.

Age as a predictor of blood transfusion was corroborated by another study, which highlights that as patient age increases, so does the probability of the patient receiving transfusion of red blood cell concentrate (KOCH et al., 2006). Other studies also showed advanced age as a risk factor for intra- and postoperative blood transfusion (MAGOVERN et al., 1996; KARKOUTI et al., 2001; KARKOUTI et al., 2006; SHEHATA et al., 2007; SOUZA; MOITINHO, 2008; VAN STRATEN et al., 2010; SÁ et al., 2011).

Regarding the relationship between advanced age and blood transfusion in the postoperative period, one study reported that the high rate of transfusion in this age group is due to anemia already present in the preoperative period (42\%), combined with surgical complications that lead to blood loss. The authors note that this age group has a low BMI, which is often a reflection of poor nutrition and health, which can lead to surgical complications and the need for blood transfusion in the intra- and postoperative periods (VEENITH et al., 2010).

Intraoperative complication as a predictive factor was not corroborated by one study that associates complications in this surgical phase with postoperative blood transfusion, among them cardiac arrest, infection of the surgical wound and gastrointestinal bleeding (MAGOVERN et al., 1996).

Bleeding is one of the primary complications in the intraoperative period of MRV surgeries that can lead to the need for transfusion. Some studies have investigated the possible causes that can lead patients to develop bleeding, and the factors that are predictors of the need for blood transfusion, among them low hematocrit and hemoglobin in the preoperative period, presence of comorbidities such as insulin-dependent diabetes mellitus, and peripheral vascular disease, myocardial infarction in the preoperative period, surgical re-exploration for any reason, and use and length of time of CBP (SOUZA; MOITINHO, 2008; VAN STRATEN et al., 2010).

\section{Blood transfusion predictors}

Most cardiac surgeries are performed using the support of CBP. One study researched this theme and showed that the use of this support and prolonged time of use both increase the risk of bleeding, and consequently the need for blood transfusion, specifically of red blood cell concentrate. In the $26.7 \%$ of cardiac surgeries in which CPB was used for longer than 120 minutes, $63 \%$ required blood transfusion. Of the 74 surgical procedures performed with a CPB time of less than 120 minutes, only $4 \%$ were transfused with four or five units of red blood cell concentrate (SOUZA; MOITINHO, 2008).

According to literature, low hematocrit and hemoglobin values in the preoperative (preprocedural anemia) or intraoperative period, along with comorbidities or severe clinical complications, presented a relationship independent of the need for blood transfusion in the intra- and post-surgical period by unleashing complications in the intraoperative period such as blood loss, increasing the risk of allogeneic transfusions (MAGOVERN et al., 1996; KARKOUTI et al., 2001; KARKOUTI et al., 2006).

The independent predictors for blood transfusion in the postoperative period presented in this study are supported by one recent study, which presented a hematocrit $\leq 40.0 \%$, use of CPB and number of distal anastomoses as independent risk factors for the prediction of blood transfusion in the postoperative period of MRV surgeries (SÁ et al., 2011)

\section{Study limitations}

Retrospective studies can mean loss of data due to loss of medical records. Thus, a future prospective study is recommended. However, it is emphasized that in this study there was no compromise of the findings in response to the objectives proposed.

\section{CONCLUSIONS}

Blood transfusions are still frequently used in cardiac surgeries, primarily MRV, with red blood cell concentrate being the predominant blood product administered in the intra- and post-surgical period.

Blood transfusion in the postoperative period is correlated with age, complications and blood transfusion in the intraoperative period. In light of the scarcity of studies regarding this topic, new studies that can corroborate or dispute the data presented in this study are necessary. The need to further discuss blood transfusion practices in cardiac surgeries, and to increase the awareness of surgical teams about the importance of the rational use of 
blood products is emphasized, thus minimizing risks and guaranteeing the safety and quality of the transfusion process.

RESUMO: Este estudo tem por objetivo identificar os fatores associados à transfusão sanguínea no pósoperatório de cirurgia cardíaca e os tipos predominantes de produtos hemocomponentes utilizados. Estudo analítico e retrospectivo realizado em um hospital de grande porte, de ensino localizado em Uberaba, Minas Gerais, Brasil. Os dados foram coletados a partir de 460 prontuários de pacientes submetidos à cirurgia cardíaca entre julho de 2005 e julho de 2010. Foram 290 (63\%) pacientes que receberam transfusões de sangue no período intra e ou pós-operatório. A idade média foi 57,9 anos; 59,6\% eram do sexo masculino; 74,8\% apresentavam hipertensão arterial sistêmica como comorbidade; e $97,2 \%$ das cirurgias foram eletivas, com revascularização do miocárdio sendo o tipo de cirurgia mais prevalente. No intra-operatório, 75 (25,9\%) pacientes receberam transfusões sanguínea, e no pós-operatório 273 (94,1\%) receberam transfusões sanguínea com concentrado de glóbulos vermelhos e foi o produto predominantemente utilzado. Houve uma associação estatisticamente significativa entre transfusão sanguínea no pós-operatório e as variáveis faixa etária, transfusão sanguínea e complicações intra-operatória. A transfusão sanguínea continua a ser um procedimento frequente em cirurgias cardíacas, e faixa etária, complicações e transfusão de sangue intra-operatória foram preditores independentes para ocorrência de transfusão sanguínea no pós-operatório.

PALAVRAS-CHAVE: Procedimentos de cirurgia cardíaca. Transfusão de sangue. Epidemiologia. Fatores de risco.

\section{REFERENCES}

AMERICAN SOCIETY OF ANESTHESIOLOGISTS. Physical Status Classification System, 1995-2009. Schaumburg: ASA, 2010.

BANBURY, M. K.; BRIZZIO, M. E.; RAJESWARAN, J.; LYTLE, B. W.; BLACKSTONE, E. H. Transfusion increases the risk of postoperative infection after cardiovascular surgery. Journal of the American College of Surgeons, Chicago, v. 202, n. 1, p. 131-138, jan. 2006. http://dx.doi.org/10.1016/j.jamcollsurg.2005.08.028

CAPRARO, L.; KUITUNEN, A.; VENTO, A. E.; SUOJARANTA-YLINEN, A.; KOLHO, E.; PETTILÄ, V. Universal leukocyte reduction of transfused red cells does not provide benefit to patients undergoing cardiac surgery. Journal of cardiothoracic and vascular anestesia, Philadelphia, v. 21, n. 2, p. 232-236, apr. 2007.

CHALEGRE, S. T.; SALERNO, P. R.; SALERNO, L. M. V. O.; MELO, A. R. S.; PINHEIRO, A. C.; FRAZÃO, C. S.; BARROS FILHO, P. B.S.; LIMA, R. C. Drenagem venosa assistida a vácuo na circulação extracorpórea e necessidade de hemotransfusão: experiência de serviço [Assisted venous vacuum drainage in extracorporeal circulation and the need for blood transfusion: experiencing the service.] Revista Brasileira de Cirurgia Cardiovascular, São José do Rio Preto, v. 26, n. 1, p. 122-127, jan./mar. 2011. http://dx.doi.org/10.1590/S0102-76382011000100021

DORNELES, C. C.; BODANESE, L. C.; GUARAGNA, J. C. V. C.; MACAGNAN, F. E.; COELHO, J. C.; BORGES, A. P.; GOLDANI, M. A.; PETRACCO, J. B. O impacto da hemotransfusão na morbimortalidade pós-operatória de cirurgias cardíacas [The impact of blood transfusion on post-operative morbidity and mortality of heart surgeries.] Revista Brasileira de Cirurgia Cardiovascular, São José do Rio Preto, v. 26, n. 2, p. 222-229, apr./jun. 2011. http://dx.doi.org/10.1590/S0102-76382011000200012

GALDEANO, L. E.; ROSSI, L. A; NOBRE, L. C; IGNÁCIO, D. S. Diagnósticos de Enfermagem de pacientes no período transoperatório de cirurgia cardíaca [Nursing Diagnoses of patients in the transoperative period of heart sugery]. Revista Latino-Americana de Enfermagem, Ribeirão Preto, v. 11, n. 2, p. 199-206, mar./apr. 2003. http://dx.doi.org/10.1590/S0104-11692003000200009 
HALL, T. S.; BREVETTI, G. R.; SKOULTCHI, A. J.; SINES, J. C.; GREGORY, P.; SPOTNITZ, A. J. Reexploration for hemorrhage following open heart surgery differentiation on the causes of bleeding and the impact on patient outcomes. Annals of thoracic and cardiovascular surgery, Tokyo, v. 7 n. 6, p. 352-357, dec. 2001.

KARKOUTI, K.; COHEN, M. M.; MCCLUSKEY, S. A.; SHER, G. D. A multivariable model for predicting the need for blood transfusion in patients undergoing first-time elective coronary bypass graft surgery.

Transfusion, Arlington, v. 41, n. 10, p. 1193-1203, oct. 2001. http://dx.doi.org/10.1046/j.1537-

2995.2001.41101193.x

KARKOUTI, K.; O'FARREL, R.; YAU, T. M.; BEATTIE, W. S. Prediction of massive blood transfusion in cardiac surgery. Canadian Journal of Anaesthesia, Toronto, v. 53, n. 8, p. 781-794, aug. 2006.

http://dx.doi.org/10.1007/BF03022795

KOCH, C. G.; LI, L.; DUNCAN, A. I.; MIHALJEVIC, T.; COSGROVE, D. M.; LOOP, F. D.; STARR, N. J.; BLACKSTONE, E. H. Morbidity and mortality risk associated with red blood cell and blood-component transfusion in isolated coronary artery bypass grafting. Critical Care Medicine, New York, v. 34, n. 6, p. 1608-1616, jun. 2006. http://dx.doi.org/10.1097/01.CCM.0000217920.48559.D8

LOURES, D. R. R.; CARVALHO, R. G.; MULINARI, L.; SILVA JUNIOR, A. Z.; SCHMIDLIN, C. A.; BROMMELSTRÖET, M.; VOITOWICZ, V. N.; DANTAS, M. H.; CHOMA, R. J.; SHIBATA, S.; FELÍCIO, M. L.; BONATTO, D. ANTUNES FILHO, N. Cirurgia cardíaca no idoso. Revista Brasileira de Cirurgia Cardiovascular, São José do Rio Preto, v. 15, n. 1, p. 1-5, 2000.

MAGOVERN, J. A.; SAKERT, T.; BENCKART, D. H.; BURKHOLDER, J. A.; LIEBLER G. A.; MAGOVERN, G. J. SR.; MAGOVERN, G.J. JR. A model for predicting transfusion after coronary artery bypass grafting. The Annals of Thoracic Surgery, Boston, v. 61, n. 1, p. 27-32, jan. 1996. http://dx.doi.org/10.1016/0003-4975(95)00808-X

MANNIEN, J.; WILLE, J. C.; KLOEK, J. J.; VAN BENTHEM, B. H. Surveillance and epidemiology of surgical site infections after cardiothoracic surgery in the Netherlands, 2002-2007. The Journal of Thoracic and Cardiovascular Surgery, Saint Louis, v. 141, n. 4, p. 899-904, apr. 2011. http://dx.doi.org/10.1016/j.jtcvs.2010.09.047

MOHNLE, P.; SNYDER-RAMOS, S. A.; MIAO, Y.; KULIER, A.; BÖTTIGER, B.W.; LEVIN, J.; MANGANO, D.T.; MULTICENTER STUDY OF PERIOPERATIVE ISCHEMIA (MCSPI) RESEARCH GROUP. Postoperative red blood cell transfusion and morbid outcome in uncomplicated cardiac surgery patients. Intensive Care medicine, Berlin, v. 37, n. 1, p. 97-109, jan. 2010.

ROGERS, M. A.; BLUMBERG, N.; HEAL, J. M.; HICKS JR, G. L. Increased Risk of Infection and Mortality in Women after Cardiac Surgery Related to Allogenic Blood Transfusion. Journal of Women's Health, Larchmont, v. 16, n. 10, p. 1412-1420, dec. 2007. http://dx.doi.org/10.1089/jwh.2007.0397

SÁ, M. P. B. O.; SOARES, E. F.; SANTOS, C. A.; FIGUEIREDO, O. J.; LIMA, R. O. A.; RUEDA, F. G.; ESCOBAR, R. R.; SOARES, A. M.; LIMA, Rde C. Predictors of transfusion of packed red blood cells in coronary artery bypass grafting surgery. Revista brasileira de cirurgia cardiovascular, São Paulo, v. 26, n. 4, p. 552-558, oct./dec. 2011.

SHANDER, A.; SPENCE, R. K.; ADAMS, D.; SHORE-LESSERSON, L.; WALAWANDER, C. A. Timing and incidence of postoperative infections associated with blood transfusion: analysis of 1,489 orthopedic and cardiac surgery patients. Surgical infections, Larchmont, v. 10, n, 3, p. 277-283, jun. 2009.

http://dx.doi.org/10.1089/sur.2007.055 
SHEHATA, N.; NAGILE, G.; ALGHAMDI, A. A.; MAZER, C. D.; HEBERT, P.; STREINER, D.; WILSON, $\mathrm{K}$. Risk factors for red cell transfusion in adults undergoing coronary artery bypass surgery: a systematic review. Vox Sanguinis, Basel, v. 93, n. 1, p. 1-11, jul. 2007. http://dx.doi.org/10.1111/j.14230410.2007.00924.x

SOUZA NETO, A. L.; BARBOSA, M. H. Analysis of immediate transfusion incidents reported in a regional blood bank. Revista Brasileira de Hematologia e Hemoterapia, São Paulo, v. 33, n. 5, p. 337-341, oct. 2011. http://dx.doi.org/10.5581/1516-8484.20110095

SOUZA NETO, A. L.; BARBOSA, M. H. Incidentes transfusionais imediatos: revisão integrativa da literatura [Immediate transfusion incidents: an integrative literature review]. Acta Paulista de Enfermagem, São Paulo, v. 25, n. 1, p. 146-150, 2012. http://dx.doi.org/10.1590/S0103-21002012000100025

SOUZA, H. J. B.; MOITINHO, R. F. Estratégias para redução do uso de hemoderivados em cirurgia cardiovascular [Strategies to reduce the use of hemoderivatives in cardiovascular surgery]. Revista Brasileira de Cirurgia Cardiovascular, São José do Rio Preto, v. 23, n. 1, p. 53-59, jan./mar. 2008.

http://dx.doi.org/10.1590/S0102-76382008000100010

VAN STRATEN, A. H.; KATS, S.; BEKKER, M. W.; VERSTAPPEN, F.; TER WOORST, J. F.; VAN ZUNDERT, A. J. SOLIMAN HAMAD, M. A. Risk factors for red blood cell transfusion after coronary artery bypass graft surgery. Journal of Cardiothoracic and Vascular Anesthesia, Philadelphia, v. 24, n. 3, p. 413417, jun. 2010. http://dx.doi.org/10.1053/j.jvca.2010.01.001

VEENITH, T.; SHARPLES, L.; GERRARD, C.; VALCHANOV, K.; VUYLSTEKE, A. Survival and length of stay following blood transfusion in octogenarians following cardiac surgery. Anaesthesia, London, v. 65, n. 4, p. 331-336, apr. 2010. http://dx.doi.org/10.1111/j.1365-2044.2009.06225.x

WERLANG, S. C.; AZZOLIN, K.; MORAES, M. A.; SOUZA, E. N. Comunicação não verbal do paciente submetido à cirurgia cardíaca: do acordar da anestesia à extubação [Non-verbal communication of heart surgery patients: from waking up from anesthesia to extubation]. Revista Gaúcha de Enfermagem, Porto Alegre, v. 29, n. 4, p. 551-556, dez. 2008.

WILLIAMS, M. L.; TRIVEDI, J. R.; DOUGHTIE, C.; SLAUGHTER, M. S. Is female sex an independent risk factor for perioperative transfusion in coronary artery bypass graft surgery? Journal of the American College of Surgeons, Chicago, v. 212, n. 3, p. 362-366, mar. 2011. http://dx.doi.org/10.1016/j.jamcollsurg.2010.12.008

WORLD HEALTH ORGANIZATION. Obesity: preventing and managing the global epidemic. Report of a WHO Consultation. Geneva: WHO, 1998. 